\title{
Prisutnost fitoplazme 'Candidatus Phytoplasma prunorum' u nasadima marelice u Baranji
}

\author{
The occurrence of 'Candidatus Phytoplasma prunorum' \\ in apricot orchards in Baranja \\ D. Ivić, Jelena Plavec, G. Ivančan
}

\section{SAŽETAK}

Tijekom 2015. godine u Baranji je došlo do masovnog propadanja nasada marelice. Iako sve upućuje da je uzrok pojave smrzavanje, određen broj voćnjaka je pregledan kako bi se u njima utvrdila eventualna prisutnost biljnih bolesti. U osam nasada marelice u Baranji sakupljena su 63 uzorka sa stabala sa simptomima odumiranja te su analizirani na prisutnost patogena 'Candidatus Phytoplasma prunorum', uzročnika europske žutice koštičavog voća. Fitoplazma je utvrđena u četiri od osam nasada, ukupno u 15 od 63 uzoraka (24\%). Masovno propadanje marelice u Baranji tijekom 2015. nije povezano sa zarazom fitoplazme ' $\mathrm{C} a$. Phytoplasma prunorum', no prisutnost tog patogena potrebno je uzeti u obzir kod uzgoja osjetljivih voćnih vrsta i proizvodnje sadnog materijala na tom području.

Ključne riječi: europska žutica koštičavog voća, fitoplazma, Prunus armeniaca L.

\begin{abstract}
During 2015, a massive dieback of apricot trees in orchards was recorded in Baranja. Although all indicated that the main cause of such decline was freezing damage, several orchards were inspected to determine the possible presence of plant diseases. Sixty-three samples from trees with decline or dieback symptoms were collected in eight apricot orchards in Baranja, and tested for the presence of 'Candidatus Phytoplasma prunorum', the causal agent of European stone fruit yellows (ESFY). ESFY phytoplasma was identified in four out of eight orchards, in 15 out of 63 samples (24\%). Massive dieback of apricots in Baranja during 2015 was not caused by ESFY phytoplasma, but the presence of this pathogen should be taken into account when growing susceptible fruit species or producing planting material in this region.
\end{abstract}

Key words: European stone fruit yellows (ESFY), phytoplasma, Prunus armeniaca $\mathrm{L}$. 


\section{UVOD}

Europska žutica koštičavog voća naziv je biljne bolesti koju uzrokuje fitoplazma 'Candidatus Phytoplasma prunorum'. Bolest je prisutna u zemljama Europe i mediteranskim zemljama Azije i Afrike, a javlja se na vrstama iz roda Prunus (Marcone i sur., 2011.). Vektor fitoplazme je lisna buha Cacopsylla pruni (Scopoli, 1763.) (Carraro i sur., 1998.).

Europska žutica koštičavog voća osobito je štetna na marelici (Prunus armeniaca L.) i japanskoj šljivi ( $P$. salicina Lindl), koje se smatraju najosjetljivijim domaćinima (Marcone i sur., 2011.). U prošlosti je pojava bolesti na marelici nazivana „klorotično uvijanje lišća“ i navodila se kao jedan od uzročnika „apopleksije“, iznenadnog odumiranja marelice. Iako jačina pojave simptoma ovisi ponajprije o sorti, podlozi i soju fitoplazme, čest je slučaj da se zaražena stabla kroz duže ili kraće razdoblje potpuno osuše (Marcone i sur., 2011.).

'Ca. Phytoplasma prunorum' u Hrvatskoj je nađena na marelici, japanskoj šljivi i breskvi (Prunus persica (L.) Batsch) u istraživanju provedenom od 2002. do 2005. (Križanac i sur., 2010). Fitoplazma je utvrđena u 11 uzoraka sakupljenih u Istarskoj, Primorsko-goranskoj, Virovitičkopodravskoj, Požeško-slavonskoj, Zagrebačkoj i Osječko-baranjskoj županiji. U istraživanju su nađene i lisne buhe (C. pruni) zaražene fitoplazmom (Križanac i sur., 2010.). Europska žutica koštičavog voća od tada nije istraživana u Hrvatskoj. Prisutnost i rasprostranjenost bolesti u različitim područjima naše zemlje i u nasadima različitih vrsta koštičavog voća u velikoj je mjeri nepoznata.

U istočnoj Slavoniji i Baranji tijekom 2015. godine došlo je do masovnog propadanja marelice u većem broju intenzivnih nasada. Kako bi se utvrdili mogući razlozi propadanja takvih razmjera, određen broj voćnjaka je pregledan u svrhu utvrđivanja eventualne prisutnosti biljnih bolesti. Iako je sve upućivalo da su voćnjaci marelice na istoku Hrvatske stradali od smrzavanja, u pregledanim voćnjacima sakupljeni su uzorci odumirućih stabala u svrhu analize na prisutnost fitoplazme ' $C a$. Phytoplasma prunorum'.

\section{MATERIJALI I METODE}

Vizualni pregledi nasada marelice provedeni su 5. lipnja, 18. rujna i 25. rujna 2015. godine. Voćnjaci su pregledani na prisutnost simptoma truleži korijena, truleži drva, bakterijskog raka (Pseudomonas spp.) i europske žutice koštičavog voća. U svrhu analize na ' $\mathrm{Ca}$. Phytoplasma prunorum', sa stabala koja se nisu potpuno osušila sakupljeno je 20 do 30 listova s različitih dijelova 
krošnje. Sakupljena su ukupno 63 uzorka iz osam nasada, dva u okolici Zmajevca te po jedan u području Belog Manastira, Banske Kose, Draža, Popovca, Suze i Kneževih Vinograda. Kultivari marelice s kojih su sakupljeni uzorci bili su različiti (Mađarska najbolja, Kečkemetska ruža, Vitillo, Stark Early Orange, Krupna rana, Bergeron, Portici).

Ekstrakcija ukupne DNA iz listova obavljena je izmijenjenim CTAB protokolom (Angelini i sur., 2001.; Šeruga i sur., 2003.) iz 1 g izrezanih lisnih žila. Ekstrahirana DNA korištena je u lančanoj reakciji polimerazom (PCR) s parom početnica P1/P7 (Deng i Hiruki, 1991.; Schneider i sur., 1995.), univerzalnima za fitoplazme. Uvjeti reakcije bili su: početna denaturacija 2 minute na $95^{\circ} \mathrm{C}, 35$ ciklusa po 1 minutu na $95^{\circ} \mathrm{C}, 1$ minutu na $58^{\circ} \mathrm{C}$ i 2 minute na $68^{\circ} \mathrm{C}$ te konačno produljivanje 10 minuta na $68^{\circ} \mathrm{C}$. Nakon prve PCR reakcije, produkti su podvrgnuti ugniježđenoj $\mathrm{PCR}$ reakciji $\mathrm{s}$ parom početnica R16(X)F1/R1 (Lee i sur., 1994.), specifičnima za 16SrX grupu. Uvjeti PCR reakcije bili su: početna denaturacija 3 minute na $95^{\circ} \mathrm{C}, 30$ ciklusa po 1 minutu na $94 \mathrm{C}, 2$ minute na $50^{\circ} \mathrm{C}$ i 3 minute na $72^{\circ} \mathrm{C}$ te konačno produljivanje 5 minuta na 2 . Produkti su vizualizira ni na agaroznom gelu nakon elektroforeze u $1 \%$ TBE puferu. Ako ih je bilo, produkti su podvrgnuti analizi polimorfizma dužine restrikcijskih fragmenata (RFLP) s RsaI i $S S p \mathrm{I}$ restrikcijskim enzimima. Kao pozitivna kontrola korišten je referentni izolat GSFY2, a kao negativna kontrola DNA nezaražene biljke domaćina te voda. Produkti RFLP-a koji su imali fragmente profila kao referentni izolat smatrani su pozitivnim nalazima fitoplazme ' $\mathrm{Ca}$. Phytoplasma prunorum'.

\section{REZULTATI I RASPRAVA}

U svih osam pregledanih nasada marelice zabilježeno je masovno propadanje stabala. Propadanje je bilo različitih razmjera, od 10-ak do gotovo $100 \%$ u nekim dijelovima pojedinih voćnjaka. U nasadima su bila vidljiva potpuno osušena stabla, djelomično osušena stabla i stabla čiji dijelovi krošnje žute, a listovi se uvijaju. U većini nasada gdje se kao podloga koristila džanarika (Prunus cerasifera Ehrh.) bilo je vidljivo bujno tjeranje izdanaka iz podloge ispod osušenih ili djelomično osušenih stabala.

Uzorci za analizu na prisutnost fitoplazme ' $\mathrm{Ca}$. Phytoplasma prunorum' nastojali su se uzimati sa stabala na kojima je bilo vidljivo žućenje i uvijanje listova. Od 63 sakupljena uzorka, fitoplazma je utvrđena u njih 15 (Tablica 1.). Najviši postotak pozitivnih uzoraka, približno $40 \%$, zabilježen je u nasadu u okolici Zmajevca i u nasadu u Banskoj Kosi. U četiri voćnjaka fitoplazma nije utvrđena niti u jednom uzorku. 
D. Ivić i sur.: Prisutnost fitoplazme "Candidatus Phytoplasma prunorum" $\mathrm{u}$ nasadima marelice $\mathrm{u}$ Baranji

Tablica 1. Učestalost fitoplazme 'Candidatus Phytoplasma prunorum' u uzorcima marelice s različitih lokacija u Baranji.

Table 1. The incidence of 'Candidatus Phytoplasma prunorum' in apricot samples from different locations in Baranja.

\begin{tabular}{|c|c|c|}
\hline $\begin{array}{c}\text { Lokacija (voćnjak) } \\
\text { Location (orchard) }\end{array}$ & $\begin{array}{c}\text { Broj pozitivnih uzoraka } \\
\text { / broj uzoraka } \\
\text { No. of postive samples } \\
\text { / No. of samples }\end{array}$ & $\begin{array}{c}\text { \% pozitivnih uzoraka } \\
\text { \% of positive samples }\end{array}$ \\
\hline Zmajevac 1 & $4 / 10$ & $40 \%$ \\
\hline Banska Kosa & $7 / 18$ & $39 \%$ \\
\hline Draž & $3 / 11$ & $27 \%$ \\
\hline Beli Manastir & $1 / 4$ & $25 \%$ \\
\hline Zmajevac 2 & $0 / 6$ & - \\
\hline Popovac & $0 / 6$ & - \\
\hline Suza & $0 / 4$ & - \\
\hline Kneževi Vinogradi & $0 / 4$ & $24 \%$ \\
\hline Ukupno & $15 / 63$ & Total \\
\hline
\end{tabular}

${ }^{1}$ - pozitivan uzorak: uzorak u kojem je utvrđena prisutnost fitoplazme ' $\mathrm{Ca}$. Phytoplasma prunorum'

${ }^{I}$ - positive sample: sample in which the presence of 'Ca. Phytoplasma prunorum' was determined

Iako je uzročnik europske žutice koštičavog voća u Hrvatskoj potvrđen prije više godina (Križanac i sur., 2010.), raširenost fitoplazme 'Ca. Phytoplasma prunorum' u komercijalnim nasadima marelice nije istraživana. Provedeno istraživanje pokazuje da je fitoplazma prisutna na području Baranje. Prisutnost bolesti potrebno je uzeti u obzir pri planiranju uzgoja marelice na tom području, s obziron na činjenicu da europska žutica koštičavog voća može biti jedan od uzroka ,apopleksije“ marelice te da može znatno umanjiti produktivnost nasada (Žežlina i sur., 2016; Torres i sur., 2004; Marcone i sur., 1995).

Bez obzira na važnost bolesti, rezultati pokazuju da naglo odumiranje stabala marelice ne mora biti povezano s europskom žuticom koštičavog voća. Zaraza fitoplazmom potvrđena je u $24 \%$ stabala sa simptomima sušenja te samo u četiri od osam pregledanih voćnjaka. Osim toga, simptomi europske žutice koštičavog voća na marelici često su blaži, do masovnog propadanja čitavih nasada ne dolazi naglo, a kultivari se razlikuju u osjetljivosti (Marcone i sur., 2011; Torres i sur., 2004; Laimer De Câmara Machado i sur., 2001). Slučaj masovnog odumiranja marelice na istoku Hrvatske u 2015. godini očigledno je povezan sa smrzavanjem stabala. Na smrzavanje upućuju simptomi, dinamika, razdoblje i intenzitet pojave simptoma, kao i masovnost same pojave. Ekstremno vruća razdoblja te iznadprosječno tople jeseni i zime mogu odužiti 
ulazak marelice u dormantnost ili potaknuti ranije kretanje vegetacije, nakon čega nagli padovi temperatura biljku oštete u tolikoj mjeri da ona tijekom proljeća i ljeta naglo propada. Uzevši u obzir događaje iz 2015., jasno je da najveću prijetnju uzgoju marelice danas predstavljaju klimatski ekstremi.

\section{LITERATURA}

ANGELINI, E., CLAIR, D., BORGO, M., BERTACCINI, A., BOUDONPADIEU, E. (2001.): Flavescence dorée in France and Italy - Occurrence of closely related phytoplasma isolates and their near relationships to Palatinate grapevine yellows and an alder yellows phytoplasma. Vitis 40(2): 79-86.

CARRARO, L., OSLER, R., LOI, N., ERMACORA, P., REFATTI, E. (1998.): Transmission of European stone fruit yellows phytoplasma by Cacopsylla pruni. Journal of Plant Pathology 80(3): 233-239.

DENG, S., HIRUKI, C., (1991.): Amplification of 16S rRNA genes from culturable and nonculturable mollicutes. Journal of Microbiological Methods 14(1): 53-61.

KRIŽANAC, I., MIKEC, I., BUDINŠĆAK, Ž., ŠERUGA MUSIĆ, M., ŠKORIĆ, D. (2010.): Diversity of phytoplasmas infecting fruit trees and their vectors in Croatia. Journal of Plant Diseases and Protection 117(5): 206-213.

LAIMER DE CÂMARA MACHADO, M., PALTRINIERI, S., HANZER, V., ARTHOFER, W., STROMMER, S., MARTINI, M., PONDRELLI, M., BERTACCINI, A. (2001.): Presence of European stone fruit yellows (ESFY or 16SrX-B) phytoplasmas in apricots in Austria. Plant Pathology 50(1): $130-135$.

LEE, I.M., GUNDERSEN, D.E., HAMMOND, R.W., DAVIS, R.E. (1994.): Use of mycoplasmalike organism (MLO) group-specific oligonucleotid primers for nested-PCR assays to detect mixed-MLO infections in a single host plant. Phytopathology 84(6): 559-566.

MARCONE, C., RAGOZZINO, A., FIRRAO, G., LOCCI, R. (1995.): Investigations on declining apricot trees associated with mycoplasma-like organisms (MLOs). Petria 5(2): 143-152. 
MARCONE, C., JARAUSCH, B., JARAUSCH, W., DOSBA, F. (2011.): European stone fruit yellows phytoplasma. U: Virus and Virus-Like Diseases of Pome and Stone Fruits (ur.: Hadidi, A., Barba, M., Candresse, T., Jelkmann, W.), APS Press, St. Paul, SAD, str. 233-241.

SCHNEIDER, B., SEEMÜLLER, E., SMART, C.D., KIRKPATRICK, B.C., (1995.): Phylogenetic classification of plant pathogenic mycoplasma-like organisms or phytoplasmas. U: Molecular and Diagnostic Procedures in Mycoplasmology (ur.: Razin S., Tully J.G.), Academic Press, San Diego, SAD, str. 369-380.

ŠERUGA, M., ŠKORIĆ, D., BOTTI, S., PALTRINIERI, S., JURETIĆ, N., BERTACCINI, A., (2003.): Molecular characterization of a phytoplasma from the aster yellows (16SrI) group naturally infecting Populus nigra L. 'Italica' trees in Croatia. Forest Pathology 33(2): 113-125.

TORRES, E., MARTÍN, M.P., PALTRINIERI, S., VILA, A., MASALLES, R., BERTACCINI, A. (2004.): Spreading of ESFY phytoplasmas in stone fruit in Catalonia (Spain). Journal of Phytopathology 152(7): 432-437.

ŽEŽLINA, I., ROT, M., KAČ, M., TRDAN, S. (2016.): Causal agents of stone fruit diseases in Slovenia and the potential for diminishing their economic impact - a review. Plant Protection Science 52(3): 1-9.

Adrese autora:

dr. sc. Dario Ivić, e-mail: dario.ivic@hcphs.hr

dr. sc. Jelena Plavec

Goran Ivančan, dipl. ing.

Hrvatski centar za poljoprivredu, hranu i selo, Zavod za zaštitu bilja Gorice 68b, 10000 Zagreb 